revista do ieb n 44 p. 27-54 fev 2007

\title{
Regularidade e ordem das povoações mineiras no século XVIII
}

Rodrigo Almeida Bastos*

Resumo

0 artigo apresenta as povoações da capitania de Minas Gerais a partir de noções de "regularidade" e "ordem” justamente consideradas no período crucial de suas formações, ou seja, na primeira metade do século XVIII. Estas são noções diferentes das que encontramos na imensa maioria dos estudos sobre a cidade colonial luso-brasileira desse e de outros períodos, que nos permitem criticar alguns mitos historiográficos há muito consolidados, como por exemplo o de que essas povoações seriam espontâneas, irregulares e desordenadas.

\section{Palavras-chave}

regularidade, ordem, decoro, urbanismo colonial, Minas Gerais.

* arquiteto e engenheiro civil, mestre em Arquitetura pela UFMG, doutorando em Arquitetura pela FAU-USP, professor do Curso de Especialização em Cultura e Arte Barroca (IFAC/ UFOP) - digobastos@gmail.com 
revista do ieb n 44 p. 27-54 fev 2007

\title{
Regularity and order in the colonial cities of Minas Gerais in the eighteenth century
}

Rodrigo Almeida Bastos

\begin{abstract}
This paper explains the colonial settlements of Minas Gerais, in the 18th century, the crucial period of their development, by using the notions of "Regularity" and "Order". These notions, as opposed to the majority of the concepts found on studies about Portuguese-American colonial cities, allow us to criticize some old historiographical myths, such as the spontaneity, irregularity and disorder of these settlements.
\end{abstract}

\section{Keywords}

regularity, order, decorum, colonial cities, Minas Gerais. 
“...na arquitectura tudo se faz por regra..."

Padre Antonio Vieira, Sermão da sexagésima

Este texto procede de uma pesquisa mais ampla ${ }^{1}$ dedicada a compreender a fábrica artístico-construtiva na capitania de Minas Gerais no século XVIII a partir dos pressupostos, procedimentos e princípios exatamente coevos à formação de seus conjuntos arquitetônicos e urbanos. Evita-se, portanto, o uso de categorias anacrônicas (como: "partido”, "função”, "identidade”, "originalidade”, "evolução", o próprio termo "barroco" e seus corolários dedutivos, formalistas e subjetivistas, redutores da análise artística), carregadas de ideologias estranhas às circunstâncias e aos regimes poético-retóricos de invenção, produção e recepção setecentistas. 0 objetivo principal da pesquisa é, portanto, reescrever a história desses conjuntos arquitetônicos e urbanos ao mesmo tempo em que se procura reconstituir a história dos fundamentos e preceitos (por exemplo: decoro, decência, conveniência, comodidade, adequação, ordem, aumento, compostura, asseio etc.) que foram considerados em suas formações. Desta feita, a análise das fontes documentais primárias e também dos tratados artísticos e teológicos considerados no período, nos quais se apresentam as matérias desses preceitos, adquire premência por seu significado teórico-metodológico.

Contemplar os conjuntos arquitetônicos e urbanos setecentistas de Minas Gerais à luz dos princípios coevos pode nos levar a compreensões diversas daquelas consagradas pela historiografia. Sob o olhar e a sensibilidade modernos - cito alguns dos autores mais importantes: Sylvio de Vasconcellos, Paulo Ferreira Santos e Roberta Marx Delson -, as povoações mineiras se consagraram como "espontâneas" e "irregulares"2. Sob o olhar e o juízo, no entanto, da primeira metade dos setecentos - período aurífero decisivo em que elas foram

1 Pesquisa desenvolvida atualmente no Doutorado, com o apoio da FAPESP.

2 Cf. VASCONCELLOS, Sylvio de. Vila Rica: formação e desenvolvimento - residências. Rio de Janeiro: Ministério da Educação e Cultura, Instituto Nacional do Livro, 1956; VASCONCELLOS, Sylvio de. Formação das povoações de Minas Gerais. In: _-____. Arquitetura no Brasil, pintura mineira e outros temas. Belo Horizonte: Escola de Arquitetura da UFMG, 1959. p. 1-6; cf. também SANTOS, Paulo Ferreira. Formação de cidades no Brasil colonial. Rio de Janeiro: Editora UFRJ, 2001; e DELSON, Roberta Marx. Novas vilas para o Brasil-colônia: planejamento espacial e social no século XVIII. Trad. de Fernando de Vasconcelos Pinto. Brasília: ALVA-CIORD, 1997. 
erigidas e acomodadas em seus núcleos primordiais -, as povoações mineiras sugerem outra consideração. Apresentarei, neste texto, as povoações de Minas Gerais à luz de noções de "regularidade" e "ordem" tal como consideradas na primeira metade do século XVIII luso-brasileiro; noções diferentes daquelas que encontramos na imensa maioria dos estudos sobre a cidade colonial luso-brasileira desse e de outros períodos; capazes não apenas de proporcionar o questionamento e a revisão crítica de uma denominação - tornando inevitável defender, como veremos, a regularidade das povoações mineiras - mas, e sobretudo mais importante, de nos conduzir a uma melhor compreensão dos procedimentos e princípios que condicionaram, naqueles tempos, a conformação de suas virtudes tão singulares.

Antes de tratar objetivamente das povoações mineiras, cumpre posicionar a questão da "regularidade" no âmbito dos estudos das povoações coloniais luso-brasileiras. De um modo geral, a noção de "regularidade" que predomina nesses estudos se caracteriza pela geometria uniforme no traçado retilíneo de arruamentos e praças; geometria esta que representaria uma proposição racional do homem, resultante da necessidade de se alcançar uma espécie de "ordem" prefigurada pelo número, pela constância, pela repetição e pela previsibilidade. Encaixam-se nesta definição não apenas os traçados urbanos dispostos em arruamentos perpendiculares entre si, gerando quadras retangulares ou propriamente quadradas, mas também as cidades, cidadelas e fortificações originadas a partir de "polígonos regulares", ou seja, cujas faces e ângulos são iguais, com traçados perimétricos e radiais. A origem dessa compreensão, por assim dizer, universal da regularidade - porque ela está presente, vale destacar, não apenas na análise da cidade colonial ibero-americana mas na generalidade dos estudos urbanos, categoria aceita praticamente como ponto pacífico entre os estudiosos ${ }^{3}$ - aplicada à arte de se fazer cidades pode remontar à própria tradição disciplinar da Geometria ${ }^{4}$. Tanto assim que é possível encontrar não apenas

3 Estudiosos da cidade e do urbanismo, historiadores, arquitetos (principalmente estes, envolvidos disciplinarmente com a análise das formas), geógrafos, sociólogos etc. evidenciam uma compreensão realmente universal da "regularidade". Encontram-se freqüentemente o termo e também as expressões: "régularité urbaine", "le plan règulier" (LAVEDAN, Pierre. Histoire de L'urbanisme. Paris: Henri Laurens, 1926), "regolarità urbana”, "città regolare", "città regolari", "ciudades regulares" etc., diretamente traduzíveis para o português e sem prejuízos semânticos. 
o termo isolado, "regularidade", mas a expressão mais específica - "regularidade geométrica" - que poderia ser adotada para os casos acima descritos, como especificação particular de um conceito cuja compreensão pode ser, a se ver adiante, mais complexa e abrangente.

A noção de "irregularidade" descende diretamente da noção de "regularidade", compreendendo obviamente o que não seria uniforme nem constante. No âmbito das cidades, é tradicionalmente aplicada aos traçados sinuosos, ditos "orgânicos"; arruamentos, largos e praças de dimensões variáveis, cruzando-se em ângulos não-retos; conjuntos arquitetônicos e urbanos em que não são apreensíveis as figuras "regulares" da geometria.

Assim expostas, as noções de "regularidade" e "irregularidade" compõem um dos binômios fundamentais da História da cidade e do urbanismo; parafraseando e ilustrando, com freqüência, uma de suas dicotomias teóricas mais tradicionais, que é a "oposição" ou a "complementaridade", segundo estudiosos como Lavedan e Pierre Pinon ${ }^{5}$, entre a chamada "cidade espontânea" e a "cidade planejada". Na tradição urbanística corrente, a "cidade espontânea" apresenta geralmente um traçado geometricamente irregular, ao passo

4 A tradição da "regularidade" como categoria elementar da Geometria (uma das artes do quadrivium) remonta ao percurso e às traduções de "Os elementos", de Euclides (séc. IV a. C.), que se filia, por sua vez, à tradição platônico-pitagórica: os "polígonos regulares" euclidianos, figuras formadas por ângulos e faces iguais, passíveis de perfeita inscrição no círculo, e os "sólidos" - traduzidos como "regulares" - platônicos. Aqui, não se pode esquecer da relevância da Matemática e da Geometria como fundamentos para a conceituação platônica da filosofia e da discussão do belo também em chave platônica. A "cidade regular" (geométrica) apresentaria os mesmos atributos das figuras "regulares": constância, repetição, previsibilidade; não necessariamente o ângulo reto, pois polígonos regulares de três ou mais de quatro faces também são, por definição, "regulares”, e seus traçados são perimétricos e radiais. Exercícios geométricos, como construção e manipulação de figuras regulares, estavam na base dos tratados e das "Aulas" de arquitetura e engenharia militar oferecidas no universo luso-brasileiro durante a colonização. Sobre a formação dos arquitetos e engenheiros militares luso-brasileiros, bem como a importância da Geometria em seus tratados e formação, cf. BUENO, Beatriz Piccolotto Siqueira. Desenho e desígnio: o Brasil dos engenheiros militares (1500-1822). 2001. 2 v. Tese (Doutorado em Arquitetura) - Faculdade de Arquitetura e Urbanismo da Universidade de São Paulo, São Paulo, 2001.

5 Cf. LAVEDAN, Pierre. Gèographie des villes (1936). Paris: Gallimard, 1959. Cf. também PINON, Pierre. La notion de ville neuve planifiée et l'historiographie de l'urbanisme. Disponível em: <http://hgtice.free.fr/colloques/rochyon 2004. htm>. Acesso em: 12 jun. 2005. 
que a "cidade planejada", consagrada pelos mitos paradigmáticos da "cidade ideal" e da "cidade moderna", é geralmente disposta em traçado uniforme, constante e regularmente geométrico, representação de uma espécie de ordem racional demiurgicamente imposta à natureza.

A permanente comparação da maioria de nossas povoações coloniais, geralmente acomodadas ao sítio, com o padrão consagrado das hispano-americanas, uniformemente geométricas em suas plantas e traçados em xadrez ou quadrícula, o famoso "damero", certamente contribuiu - e Nestor Goulart já alertou a respeito ${ }^{7}$ - para nos apegarmos a uma compreensão estrita e uniformemente geométrica da regularidade. Presente já nos viajantes europeus que visitaram a América portuguesa no século XIX, essa noção "geométrica" domina também o panorama no século XX, indicando a consolidação de uma verdadeira tradição historiográfica; desde Sérgio Buarque de Holanda, no texto fundador Raízes do Brasil, até pesquisas e publicações mais recentes ${ }^{8}$.

Uma das mais importantes contribuições dessa tradição é o estudo fundamental de Paulo Ferreira Santos - Formação de cidades no Brasil-colonial -, apresentado em Coimbra, em 1968, no Colóquio de Estudos Luso-brasileiros, publicado em forma de separata. Ainda que uma de suas principais intenções tenha sido valorizar, diante da geometria quadricular dos traçados das cidades hispano-americanas, os aspectos positivos que advinham de uma reavaliada "irregularidade" dos traçados de nossas

6 Reconhecendo a contribuição de especialistas, Walter Rossa alertou para o fato de que, efetivamente, "entre a totalidade das cidades hispano-americanas é percentualmente reduzido o número de casos em damero". ROSSA, Walter. 0 Urbanismo regulado e as primeiras cidades coloniais portuguesas. In: CARITA, Helder; ARAÚJO, Renata (Coord.). Colectânea de estudos: universo urbanístico português, 1415-1822. Lisboa: CNCDP, 1998. p. 507-536. Já se relativiza, portanto, o reconhecimento desse tipo de traçado como o padrão típico aplicado na colonização hispano-americana. Todavia, e sobretudo durante o período em que se registraram as primeiras contribuições da historiografia urbana da América Ibérica, ele foi realmente consagrado como paradigma da política de colonização e povoamento espanhol.

7 REIS FILHO, Nestor G. A urbanização e o urbanismo na região das Minas. São Paulo: FAU/USP, 1999. p. 19. (Cadernos do LAP, 30).

8 Cf. AZEVEDO, Paulo Ormindo de. Urbanismo de traçado regular nos dois primeiros séculos da colonização brasileira: origens. In: CARITA, Helder; ARAÚJO, Renata (Coord.). Colectânea de estudos: universo urbanístico português, 1415-1822. Lisboa: CNCDP, 1998. p. 39-70. 
povoações coloniais ${ }^{9}$, Paulo Santos concluiu uma certa "evolução dos traçados de cidades e vilas no Brasil”, por ele "examinada à luz de casos típicos dessa evolução”. Paulo Santos reconheceu, então, quatro tipos de traçados, que iam desde os "traçados inteiramente irregulares", passando pelos "traçados de relativa regularidade", pelos "traçados que inicialmente foram irregulares, sendo depois refeitos para adquirirem perfeita regularidade”, até chegar aos "traçados perfeitamente regulares", de que as vilas do período pombalino foram protagonistas ${ }^{10}$.

A identificação de uma "evolução dos traçados" no "Brasil-colonial", dirigindo-se do "inteiramente irregular" ao "perfeitamente regular", poderia até soar como um paradoxo; afinal, um dos objetivos declarados de Paulo Santos era valorizar as qualidades cenográficas e acomodatícias da "cidade irregular". Mas a referida "evolução", é preciso alertar, se aplicava aos "traçados”, e não à cidade em si, o que levou Paulo Santos a recomendar, recorrendo à leitura de Saarinen para as cidades medievais, que as cidades do "Brasil Colonial" fossem "julgadas", estes são os termos, em sua "atmosfera arquitetônica tridimensional, mais do que nos traçados bidimensionais". Para ele, essas cidades eram coerentes com os "meios de transportes" contemporâneos e com o "sistema de vida aconchegado" que nelas se desenvolvia, uma espécie de alerta metodológico, bastante pertinente, inclusive, contra certa predominância de estudos urbanos que priorizam a morfologia dos traçados ${ }^{11}$. Ademais, se para Paulo Santos a questão da forma não poderia ser subestimada, as cidades coloniais irregulares - assim como as medievais - também teriam suas virtudes, exaltadas diante das críticas, já acir-

9 SANTOS, Paulo Ferreira. Formação de cidades no Brasil colonial. Rio de Janeiro: Editora UFRJ, 2001. p. 18.

10 Cf. SANTOS, Paulo Ferreira. Formação de cidades no Brasil colonial. Rio de Janeiro: Editora UFRJ, 2001. p. 58-71. Nos últimos anos, a proeminência de estudos sobre o período pombalino, em que vilas e cidades numerosamente apresentam, em plantas e efetividade, geometrias mais rígidas, também contribuiu para mantermos a noção de regularidade subordinada à geometria uniforme dos arruamentos.

11 A prioridade das análises urbanas que partem da forma bidimensional dos traçados urbanos - para as quais as noções de irregularidade e regularidade geométrica constituem fundamentos - tem sido também revista e bastante relativizada pelos trabalhos mais recentes da história cultural e da geografia urbana. 
radas na década de 1960 , dirigidas contra a previsibilidade e a monotonia "impecavelmente regular" das cidades modernas:

a irregularidade da traça cria situações curiosas, perspectivas que a irregularidade favorece, e quiçá resultados imprevistos pela valorização que confere a determinados ângulos dos edifícios, que não se teria em mira exaltar [...]. Os arquitetos medievos, como os nossos mestres coloniais, tinham experiência desses resultados e de antemão sabiam que podiam contar mais seguramente com efeitos dessa irregularidade para os tipos de edifícios que usavam do que com a monotonia das soluções impecavelmente regulares, que tem sido predileção dos contemporâneos. ${ }^{12}$

Embora tenha contribuído para convalidar uma acepção estritamente geométrica de regularidade aplicada às povoações coloniais, o estudo de Paulo Santos foi relevante para o reconhecimento e a valorização das especificidades das "cidades portuguesas do Brasil”, em um contexto intelectual ainda fortemente marcado pelo severo diagnóstico fornecido por Sérgio $\mathrm{Bu}$ arque de Holanda em 1936, ou seja: a "desordem" resultante do "desleixo" com que os portugueses implantaram, ou permitiram que fossem implantadas, povoações em sua colônia americana ${ }^{13}$. Corroborava esta compreensão o também importante trabalho de Robert Smith sobre a arquitetura colonial luso-brasileira, em que a "ignorância" da "ordem", por parte dos portugueses, terminava identificada com a "irregularidade" (geométrica) do arruamento de suas cidades:

12 SANTOS, Paulo Ferreira. Formação de cidades no Brasil colonial. Rio de Janeiro: Editora UFRJ, 2001. p. 18.

13 Cf. HOLANDA, Sérgio Buarque de. 0 semeador e o ladrilhador. In: Raízes do Brasil. São Paulo: Companhia das Letras, 1997. cap. 4, p. 93-138. Estudiosos têm se dedicado ao exame das ideologias, contradições e métodos subjacentes a Raizes do Brasil, escrito entre 1927 e 1936; aspectos circunstanciais que teriam condicionado as teorias de Holanda, como por exemplo a compreensão da incipiente urbanização brasileira nos alvorecer da década de 1930, a influência de sua formação intelectual na Alemanha e a afinidade ao método Jungiano dos arquétipos radicais. Para uma apanhado sumário dessas pesquisas, cf. o primeiro capítulo da dissertação de mestrado de TORRÃo FILHO, Amílcar. Paradigma do caos ou cidade da conversão?: a cidade colonial na América portuguesa e o caso da São Paulo na administração do Morgado de Mateus (1765-1775). 2004. 338 f. Dissertação (Mestrado em História) - Instituto de Filosofia e Ciências Humanas, Universidade Estadual de Campinas, 2004. 
a ordem era ignorada pelos portugueses como assinalavam deliciados os viajantes. As suas ruas, ironicamente chamadas 'direitas', eram tortas e cheias de altibaixos, as suas praças de ordinário irregulares. ${ }^{14}$

Logo nas primeiras linhas de seu estudo, Paulo Santos reviu o famoso trabalho de Holanda, declarando ser "difícil conciliar esse retrato" da "desordem" com a idéia de havermos reconhecido algumas dessas cidades com a categoria de "monumentos nacionais".

É que naquela aparente desordem [...], a inexistência de um traçado prévio ou de uma idéia geratriz, existem uma coerência orgânica, uma correlação formal e uma unidade de espírito que lhe dão genuinidade. Genuinidade como expressão espontânea e sincera de todo um sistema de vida, e que tantas vezes falta à cidade regular, traçada em rígido tabuleiro de xadrez.

A “irregularidade" e a "espontaneidade" - "aparente desordem" - adquiriram sinais de "unidade", de "coerência orgânica" e, principalmente, de "genuinidade". A teoria de Paulo Santos buscou inverter a hierarquia habitual de julgamento, trazendo à discussão valores considerados implícitos à "irregularidade" que seriam capazes de revelar uma "genuinidade" das cidades cujos traçados assim se caracterizassem. Numa relação introdutória de dez cidades - é preciso notar -, as seis primeiras citadas por Paulo Santos eram de Minas Gerais: "Ouro Preto, São João del Rei, Mariana, Diamantina, Serro, Tiradentes”. 0 exemplo empírico utilizado por Paulo Santos para entusiasmar, de início, a anuência do leitor à sua tese foi justamente a primeira delas, Ouro Preto (FIG. 1); a única, naquele momento, a possuir oficialmente o título de "monumento nacional", paradigma da "espontaneidade" e da "irregularidade" aplicadas não apenas, mas especialmente, às povoações mineiras.

Nas cidades mineiras, à irregularidade da planta soma-se o acidentado do terreno para valorização dos aspectos, como, por exemplo, na Igreja de São Francisco de Assis de Ouro Preto, duplamente favorecida, para quem vem de cima como para quem vem de baixo. ${ }^{15}$

14 SMITH, Robert. Arquitetura colonial. Salvador: Livraria Progresso, 1955. p. 12. (As artes na Bahia, pt. 1). 
Embora a hipótese da "desordem" defendida por Sérgio Buarque de Holanda esteja atualmente superada, a noção de regularidade considerada nos estudos da cidade colonial lusobrasileira ainda é devedora de uma noção de "ordem" representada pela geometria uniforme. Conquanto tenhamos aprendido, nas últimas décadas, a considerar as virtudes da cidade colonial luso-brasileira a despeito da não-ortogonalidade ou da nãouniformidade de seus arruamentos, edifícios e praças - devido à contribuição, nas últimas décadas, de muitos pesquisadores luso-brasileiros, como Sylvio de Vasconcellos e o próprio Paulo Santos - a regularidade ainda é compreendida como predominantemente atrelada ao rigor da uniformidade, principalmente a do ângulo reto. Cumpre indagar: se já é possível intuir que o sentido de ordem das cidades luso-brasileiras não é o geomé-

15 SANTOS, Paulo Ferreira. Formação de cidades no Brasil colonial. Rio de Janeiro: Editora UFRJ, 2001. p. 18-19. Já em 1951, em Subsídios para o estudo da arquitetura religiosa em Ouro Preto, Rio de Janeiro: Livraria Kosmos, distribuidora, 1951, Paulo Santos ressaltara a "espontaneidade" de Ouro Preto, uma cidade nascida, em seus termos, como que "a esmo", "à-vontade derramada", "pitoresca", conferida por isso em "graça" e "originalidade", uma cidade, interessa atentar, em que é "indefinível" a "forma geométrica": "Êste [o vale onde a cidade foi implantada] nada tem de plano: seios opulentos separados pelos sulcos fundos das vertentes dos córregos. A cidade ondula sobre êsses seios. As ruas sobem, descem, viram ora para um, ora para outro lado, em ângulos ou curvas imprevistos. Como fitas coladas por criança travêssa sôbre um mapa de relevo. Como trilhas seguidas a êsmo pelos tropeiros [...]. Os lotes de terreno, quase todos, são estreitos e alongados, e de forma geometricamente indefinível. 0 casario [...] trepa pelas ladeiras, esconde-se nos buracos, debruça-se sôbre o alcantilado das encostas, num à-vontade derramado, que longe de prejudicar a harmonia do conjunto, ao contrário, confere-lhe graça, pitoresco, originalidade [...]. A arquitetura da cidade é tão espontânea e natural e tanto se funde com a paisagem que, pode dizer-se, faz parte da terra, como as árvores da floresta ou o mato do chão". SANTOS, Paulo F. Subsídios para o estudo da arquitetura religiosa em Ouro Preto. Rio de Janeiro: Kosmos, 1951. p. 17-18. Também na década de 1950, mais precisamente em 1956 e 1959, Sylvio de Vasconcellos consagrou definitivamente os aspectos e qualidades urbanas positivas decorrentes do dito desenvolvimento "espontâneo" e da dita "irregularidade" das povoações mineiras do século XVIII: perspectivas "cenográficas", cidades que se "harmonizam" com a paisagem circundante e "participam", se amoldam, também, à "vida" de seus habitantes, como "entidades também vivas", orgânicas e "livres das regulações metropolitanas". Cf. VASCONCELLOS, Sylvio de. Vila Rica: formação e desenvolvimento - residências. Rio de Janeiro: Ministério da Educação e Cultura, Instituto Nacional do Livro, 1956; e também VASCONCELLOS, Sylvio de. Formação das povoações de Minas Gerais. In: Arquitetura no Brasil, pintura mineira e outros temas. Belo Horizonte: Escola de Arquitetura da UFMG, 1959. p. 1-6 
trico estrito das cidades-xadrez hispano-americanas, por que não pensar também que, analogamente, o sentido de "regularidade" daquelas possa ser diferente ou mais abrangente do que o sentido "geométrico" da regularidade dessas? Seria possível identificar uma noção ou noções de regularidade características do "urbanismo" ou "arte da ruação" portuguesa ${ }^{16}$ ? Regularidades estas condicionadas, obviamente, aos períodos e contextos específicos em que surgem e se desenvolvem?

Algumas tentativas de contornar esse exclusivismo da regularidade geométrica foram empreendidas por alguns estudiosos, embora não tivessem pretendido desafiar diretamente o problema do anacronismo categórico. A principal delas talvez tenha sido a de Nestor Goulart Reis Filho, em um trabalho dedicado especialmente à "Urbanização e o urbanismo da região das Minas"17, atuais estados de Minas Gerais, Mato Grosso e Goiás. Numa parte subtitulada "Questões teóricas específicas”, Reis Filho alertou para a prevalência do sentido geométrico da noção de "regularidade", adotando, segundo suas palavras, um “conceito mais geral”, "corrente nas pesquisas científicas”. Sob a noção geométrica, restaria pouco a fazer senão declarar a total irregularidade das povoações; ou então identificar algumas prováveis exceções - sugeriria Paulo Santos - de "relativa regularidade”, como a que geralmente recebe Mariana, por ocasião das reformas antecedentes à sua elevação para a condição de “cidade", ou os acréscimos de Vila Boa de Goiás no período pombalino. Mas Nestor se esquiva dessa noção tradicional e desenvolve um conceito interessante para a análise do processo de formação dessas povoações. Além de seu sentido geométrico - Nestor também o reconhece neste e em outros trabalhos -, a regularidade pode ser entendida como "existência de repetições de determinadas características”. Também "há regularidade", segundo ele, quando se pode observar, em um "processo", "séries de eventos" que possuem características que se repetem. 0 processo em questão é a "urbanização”, e os eventos repetitivos,

16 Rafael Moreira alertou para os usos do termo "urbanismo" ao se tratar da cidade colonial luso-brasileira. MOREIRA, Rafael. A arte da ruação e a cidade luso-brasileira (sécs. XVI-XVIII). São Paulo: FAU/USP, 2003. p. 8-30. (Cadernos do LAP, 37). Compreendo o termo "urbanismo", neste trabalho, como o conjunto de tradições, práticas e princípios que condicionaram os processos de implantação, aumento e conservação de povoações.

17 REIS FILHO, Nestor Goulart. A urbanização e o urbanismo na região das Minas. São Paulo: FAU/USP, 1999. (Cadernos do LAP, 30). 
o que ele denomina como "formas - ou 'modalidades' - de disciplinas urbanísticas" ${ }^{18}$.

Nestor Goulart observou três dessas modalidades. As duas primeiras se referem às "plantas das cidades" ("continuidade" do "alinhamento" entre as edificações, "largura constante para as vias públicas"), e uma outra para ordem e controle das "formas e [d]a aparência das fachadas". Na generalidade das "urbanizações", essas modalidades disciplinadoras se repetem, são constantes, e também geram padrões de regularidade ou repetição formal, utilizados por Nestor como exemplos ${ }^{19}$.

A "regularidade científica" adotada por Nestor é sem dúvida um avanço. Não apenas porque questiona a supremacia da noção estritamente geométrica de regularidade, reivindicando um "conceito mais geral" para o termo, mas também porque chama a atenção para "processos" e "diretrizes" que, observados em "repetições regulares", contribuíam para a constituição da cidade colonial. É uma regularidade efetivada, ainda que eventualmente não cumprida, como ele mesmo adverte, através das atividades das câmaras, vereadores, arruadores, na tentativa de disciplinar espaços, edifícios públicos e privados e criar "padrões" e "cenários" urbanos. Se a "regularidade geométrica" tem sido tradicionalmente aferida pela repetição e pela constância de dimensões e medidas, a "regularidade científica" de Nestor Goulart é observada na repetição e na constância de eventos e "padrões” urbanísticos. É uma noção por certo mais abrangente, capaz de compreender também - porque igualmente fundamentada na repetição e na constância de elementos - a noção geométrica de regularidade; é uma noção passivel, portanto, de utilização no exame "mais geral" das povoações coloniais, não apenas das mineradoras. É uma contribuição crítica bastante importante, mas não é ainda a noção de regularidade que buscamos, exatamente contemporânea à formação dos conjuntos urbanos analisados.

\section{Uma noção coeva de "regularidade"}

Uma noção também mais abrangente de "regularidade" era literalmente declarada nas primeiras décadas do século XVIII, em duas obras bastante significativas: num dos mais

18 REIS FILHO, Nestor Goulart. A urbanização e o urbanismo na região das Minas. São Paulo: FAU/USP, 1999. p. 19. (Cadernos do LAP, 30).

19 Ibid. p. 19-34. (Cadernos do LAP, 30). 
completos vocabulários de língua portuguesa, o Vocabulário Portuguêz, e Latino, Áulico, Anatomico, Architectonico... ${ }^{20}$, dedicado pelo padre jesuita D. Raphael Bluteau em 1712 ao próprio rei D. João V, e também na obra de um dos importantes tratadistas portugueses de arquitetura, Manoel de Azevedo Fortes, "0 engenheiro português" (1728/29).

0 primeiro sentido registrado por Raphael Bluteau para o verbete "REGULARIDADE" é muito claro: "Disciplina regular, observância regular, regras bem guardadas". 0 termo "REGULAR" usava-se "metaforicamente", segundo o jesuita, para se falar de "cousas, que se fazem com regra, ordem etc."; "Regular" era adjetivo de "cousa segundo as regras da Arte". 0 sentido "geométrico" dos termos também comparece, e o exemplo utilizado é oportuno: "Fortificação regular, he aquella, cujas faces, e angulos, saõ iguaes" ${ }^{21}$. Fica evidente que a "regularidade" não se caracterizava apenas pela constância ou igualdade de medidas, definição derivada da Geometria, porque ela era, primordialmente, uma espécie de virtude alcançada pela "disciplina" na qual se "observam" as "regras da arte".

Manoel de Azevedo Fortes também reconheceu a "regularidade" com essa mesma, e maior, abrangência. Desenvolvendo ao "engenheiro português" a importância de "ajustar" as obras às circunstâncias e "imposições do meio" ${ }^{2}$, recomendou que

pelos preceitos, e regras de huma fortificação regular devem obrar os engenheiros na irregularidade dos terrenos, aproximando-se quanto for possível à regularidade, isto he, à oservancia das regras da fortificação regular $[. . .]^{23}$

Ambos reconheceram a regularidade de atributos geométricos, mas devia predominar mais abrangente - como sinalizam

20 BLUTEAU, Raphael. Vocabulário portuguêz, e latino, áulico, anatomico, architectonico... Coimbra: Real Collegio das Artes da Companhia de Jesus, 1712. $10 \mathrm{v}$.

21 Cf. BLUTEAU, Raphael. Regular; Regularidade. In: Vocabulário portuguêz, e latino, áulico, anatomico, architectonico... Coimbra: Real Collegio Das Artes da Companhia de Jesus, 1712. v. 7, p. 206-207.

22 FORTES, Manoel de Azevedo. O engenheiro portuguez, 1728 apud BUENO, Beatriz Piccolotto Siqueira. Desenho e desígnio: o Brasil dos engenheiros militares (1500-1822). 2001. 2 v. Tese (Doutorado em Arquitetura) - Faculdade de Arquitetura e Urbanismo da Universidade de São Paulo, São Paulo, 2001. p. 486. 
o vocabulário setecentista e as recomendações do tratado - a noção de "regularidade" como "observância regular" de "preceitos" e "regras da arte".

Atentei para esta noção coeva de "regularidade" enquanto pesquisava a influência da noção de "decoro" na implantação de novas povoações em Minas Gerais na primeira metade do século XVIII ${ }^{24}$. 0 "decoro", ou "conveniência”, foi um dos princípios ético-retóricos fundamentais ao pensamento e à arte ocidental desde a antiguidade, consagrado pela longa tradição da Retórica e da Poética como preceito regular de adequação e conveniência de meios e fins, orientação pertinente a praticamente todas as manifestações técnicas e artísticas, retórica, poesia, teatro, pintura, escultura, arquitetura etc. Incentivada pelo contexto teológico-retórico luso-brasileiro dos séculos XVII e XVIII, recomendada ainda pelos tratados antigos e modernos de arquitetura e engenharia militar traduzidos ou redigidos pelos portugueses a partir do século XVI - como o De architectura de Vitrúvio, em que o decor compareceu como um dos seis princípios fundamentais da arquitetura, juntamente com ordenatio, dispositio, symmetria, eurithmia e distributio - a consideração do decoro colaborou decisivamente para a afirmação de uma política de implantação de povoações na qual rezava, além da escolha dos sítios "mais convenientes", uma orientação primordial de adequação "por ordem” às circunstâncias, costumes e preexistências físicas, naturais e construídas, visando à conveniência final da obra ou da povoação tanto à política teológica metropolitana quanto aos interesses dos colonos.

Vejamos a definição de um tratadista português para o "decoro", o padre jesuíta Luiz Gonzaga, lente durante a primeira década dos setecentos na Aula de Esfera do Colégio de Santo Antão e "mestre" 25 do futuro rei D. João V - durante o reinado do qual (1706-1750) se situam a fundação e o florescimento das primeiras vilas mineiras. Sua obra é o "Exame Militar”, e a fonte é Vitrúvio, na tradução de Daniele Barbaro ${ }^{26}$ :

23 FORTES, Manoel de Azevedo. 0 engenheiro portuguez, 1728 apud BUENO, Beatriz Piccolotto Siqueira. Desenho e desígnio: o Brasil dos engenheiros militares (1500-1822). 2001. 2 v. Tese (Doutorado em Arquitetura) - Faculdade de Arquitetura e Urbanismo da Universidade de São Paulo, São Paulo, 2001. (grifo nosso).

24 BASTOS, Rodrigo Almeida. A arte do urbanismo conveniente: o decoro na implantação de novas povoações em Minas Gerais na primeira metade do século XVIII. 2003. 240 f. Dissertação (Mestrado em Arquitetura) - Escola de Arquitetura, Universidade Federal de Minas Gerais, Belo Horizonte, 2003. 
Apparencia, Decoro, e Fermosura da planta, ou praça, se equivoca tambem m. t $^{\circ}$ com Eurithmia, tem porem sua differença; porq a Eurithmia so trata do decoro da boa destribuiçaõ das suas partes, em o lugar q ham de ter no risco : mas o Decoro he a propriede [propriedade] das partes da praça por ordem ao sitio, q se tem escolhido, por ordem ao costume com q se dispoem, e per ordem a natureza do com q se faz. Sirva de exemplo huma praça q se manda fazer, o engenheiro, busca este sitio ou lugar da fortificaçaõ a onde possa ser conveniente. Busca este sitio mais apto $\mathrm{p}^{\text {a }}$ o fim $\mathrm{q}$ se pertende, dispoem as partes da praça segundo hum costume, ou methodo de fortificar, e segundo este vay dando a cada huma das partes, o que estas per sua natureza pedem [...] e a planta, q representa tudo isto se diz decoroza. ${ }^{27}$

0 “decoro" ("aparência”, "formosura”) desenvolvido por Gonzaga implicava a consideração às tradições e costumes - éticos, construtivos e materiais -, levando-se em conta inclusive o sítio de implantação que se deveria escolher "onde possa ser conveniente", "mais apto para o fim que se pretende". 0 decoro era uma "propriedade" das "partes" da povoação ou edificação "por ordem" a esses fatores, diretamente condicionada à "natureza" de cada uma delas em si e em relação ao conjunto da obra. "Por ordem" ao sítio, "por ordem" ao "costume" com que se edifica e "por ordem" à "natureza" da "parte", finalidade e materiais. Uma noção de "ordem" aparece aqui não como um atributo de medida ou uniformidade, alcançada formalmente por geometria abstrata predefinida, mas acima de

25 Cf. BUENO, Beatriz Piccolotto Siqueira. Desenho e desígnio: o Brasil dos engenheiros militares (1500-1822). 2001. 2 v. Tese (Doutorado em Arquitetura) - Faculdade de Arquitetura e Urbanismo da Universidade de São Paulo, São Paulo, 2001. p. 405-407 passim.

26 BUENO, Beatriz Piccolotto Siqueira. Desenho e desígnio: o Brasil dos engenheiros militares (1500-1822). 2001. 2 v. Tese (Doutorado em Arquitetura) - Faculdade de Arquitetura e Urbanismo da Universidade de São Paulo, São Paulo, 2001. p. 407.

27 GONZAGA, Luiz. Exame militar apud BUENO, Beatriz Piccolotto Siqueira. Desenho e desígnio: o Brasil dos engenheiros militares (1500-1822). 2001. 2 v. Tese (Doutorado em Arquitetura) - Faculdade de Arquitetura e Urbanismo da Universidade de São Paulo, São Paulo, 2001. p. 410 (grifo nosso). "Praças” são as "Vilas e Cidades", segundo comentário de BUENO (p. 440) sobre a terminologia apresentada no tratado de Serrão Pimentel. Bluteau também a traz, no início do séc. XVIII, no sentido pelo qual a entendemos hoje: "Praça. Lugar publico, plano \&t espaçoso, nas Cidades, Villas, \&tc. Praça onde se compra, \&t vende [...]".BLUTEAU, Raphael. Praça. In: - Vocabulário portuguêz, e latino, áulico, anatomico, architectonico... Coimbra: Real Collegio Das Artes da Companhia de Jesus, 1712. v. 6, p. 665-666. 
tudo como uma condição de relação circunstancial entre a fábrica e seu contexto, capaz de proporcionar unidade às "partes" de uma planta que, desse modo satisfeita, poder-se-ia dizer "decorosa”. Esta “ordem”, na definição decorosa de Gonzaga, constituía um princípio, e não simplesmente um atributo; um princípio apto a presidir e a orientar a organização da planta; a estimular relações oportunas e convenientes entre as "partes" componentes do todo, finalmente conveniente em proporções, ajustes e finalidades. Esta “ordem”, por assim dizer, de ajuste e adequação entre as partes, era uma condição inerente à ação do engenheiro, a ser efetivada com juízo, engenho e prudência.

Demais tratadistas portugueses próximos ao período também desenvolveram essa virtude de ajustar ordenadamente as partes de uma planta, edificação ou povoação, principalmente em relação às condições do sítio. 0 próprio trecho supracitado de Azevedo Fortes relativo à "regularidade" é um exemplo. Sua recomendação repousava especificamente no "ajuste" dos elementos e partes construtivas às circunstâncias do sítio. "Ajustar", segundo o Vocabulário de Raphael Bluteau, nos envia à noção de "adequar", como tornar uma coisa "semelhante" à outra: "Igualar uma cousa fazendoa semelhante à outra, ou em tudo, ou em parte. Aquare, adaquare”; mas nos envia também às noções de "conformidade" e "conveniência”, como "boa ordem" - atente-se para a expressão - das coisas entre si. "Ajustar. Preparar. Por em ordem. Aptare. Cic [Cícero]. Ajustar. Concertar huma cousa, \& convir nella”. "Ajustado" é aquilo que apresenta "conformidade", assim como o "Ajustamento. Conformidade, \& boa ordem das cousas entre si”. Bluteau refere-se explicitamente à noção poético-retórica de "composição", ou “disposição", “conveniente e apta composição, ou disposição, das coisas" (literalmente: “Conveniens, aptaque rerum compositio, ou dispositio" ${ }^{28}$; no âmbito em questão, das várias partes do edifício ou da povoação.

Outros tratados portugueses também sinalizaram a importância de uma adequação regular aos contextos em que se precisava dar "ajuste" e "boa ordem". Serrão Pimentel, que apresentou em 1680 o seu "Methodo lusitanico de desenhar as fortificaçoens das praças regulares e irregulares...”, alertou para a dificuldade de se construir com impecável regularidade (geométrica), ao observar que, na maioria dos casos, se fortificam

28 Cf. BLUTEAU, Raphael. Ajustado; Ajustamento; Ajustar. In: Vocabulário portuguêz, e latino, áulico, anatomico, architectonico... Coimbra: Real Collegio Das Artes da Companhia de Jesus, 1712. v. 1, p. 201-202. (trad. nossa). 
"de novo" “cidades, vilas e lugares antigos”, não sendo possível "dispor as partes interiores com a perfeição que nas que de novo se fabricaõ; mas convem que nos cheguemos quanto puder ser á mayor regularidade", evitando-se "demolições excessivas"29. Referindo-se a Palmanova, cidade militar projetada por Scamozzi no final do século XVI, de estrita e rigorosa regularidade geométrica, figurada por um eneágono, Serrão Pimentel sugeriu algumas medidas para praças e vias, mas terminou convocando o engenheiro militar "de juízo e boa consideração" a dispor conforme a "capacidade da povoação", e a "accomodar as mais particularidades com bom discurso" 30 , ou seja, com bom "uso da razão" "31; Serrão Pimentel privilegiou nitidamente uma acomodação das partes da povoação ao conjunto de circunstâncias apresentadas pelo contexto preexistente, a serem conformadas e ajustadas às aptidões necessárias e convenientes que constituíam a finalidade civil ou militar da povoação. Se "ajustar-se às imposições do meio" representava para o engenheiro de Azevedo Fortes um preceito racional utilizado para atingir conformidade e conveniência entre as "partes" - "boa ordem", enfim -, para Serrão Pimentel, era também o bom "uso da razão" e da experiência - o "bom discurso" - que oferecia ao engenheiro o "método" mais apropriado para "acomodar" prudentemente as povoações e suas "particularidades”.

Constatar a consideração do "decoro" ou da "conveniência” nos processos povoadores na capitania de Minas Gerais - um dos "preceitos regulares", uma das "regras da arte" lusobrasileira de edificar, arruar e povoar - não apenas permitiu criticar a designação "espontânea” aplicada às suas povoações, como também reconhecê-las a partir de uma noção de "regularidade" que, naqueles tempos, significava antes de tudo a "observância" a essas "regras" e "preceitos" competentes à arte de edificar. Muito mais importante do que permitir esse tipo de

29 PIMENTEL, Luís Serrão. Methodo lusitanico de desenhar as fortificaçoens das praças regulares e irregulares... Parte I, Secção II, Cap. XI apud BUENO, Beatriz Piccolotto Siqueira. Desenho e designio: o Brasil dos engenheiros militares (1500-1822). 2001. 2 v. Tese (Doutorado em Arquitetura) - Faculdade de Arquitetura e Urbanismo da Universidade de São Paulo, São Paulo, 2001. Anexo II: Documentação primária e secundária de interesse.

30 PIMENTEL apud BUENO, op. cit., p. 450-451.

31 Cf. BLUTEAU, Raphael. Discurso. In: Vocabulário portuguêz, e latino, áulico, anatomico, architectonico... Coimbra: Real Collegio Das Artes da Companhia de Jesus, 1712. v. 2, p. 245. 0 primeiro sentido em Bluteau para o termo "Discurso" é: "Uso da razão. Rationis usus". 
revisão crítica - empresa inelutável da historiografia -, o decoro tem proporcionado uma chave bastante interessante para a compreensão dos próprios processos de formação das povoações.

Na virada para o século XVIII, quando a empresa mineradora deu indícios de sucesso, a coroa portuguesa procurou se estabelecer definitivamente nos novos "descobrimentos". Ao incentivar o "sossego", a "acomodação" e a "permanência” dos povos e das povoações, procurou-se conciliar as conveniências metropolitanas e as conveniências coloniais, concentrando-as, a partir de 1711, em vilas equipadas com um organismo administrativo municipal - as câmaras - às quais tocavam matérias de responsabilidade edilícia, zelo e coordenação das atividades competentes ao "bem comum", "aumento" e "conservação" da "res publica" edificada. Interessava à coroa portuguesa a construção e a conservação de povoações decorosas, cômodas e decentes, estruturas materiais necessárias cujos efeitos e proveitos desempenhavam representações retoricamente discursivas da "dignidade" e da "decência" do "corpo místico"32 do reino católico português. "Novas povoações”, assim denominadas, se fundaram e se implantaram, então, sobre arraiais preexistentes; para as quais se solicitaram, apropriada e oportunamente, novas estruturas urbanas, edifícios e arruamentos, declaradamente requeridos como "convenientes" e melhor "proporcionados", mais "seguros", "dignos" e "ornados", enquanto a sociedade se estabilizava em associações leigas, ordens terceiras, irmandades e confrarias.

A ereção das vilas era geralmente coordenada pelo governador da capitania, como um ato de efetiva instalação política. Elegeram-se - e os termos de ereção das vilas fazem costumeira referência a isso - os sítios considerados mais "cômodos", "capazes" e "convenientes”. Na ereção da Vila de Nossa Senhora do Carmo ${ }^{33}$,

32 "Corpo místico" é a expressão com a qual se designam: 1º) a Igreja como Corpus ecclesiae mysticum, em analogia ao Corpus hominis naturale, a qual é compreendida como o corpo de Cristo constituído misticamente; e $2^{\circ}$ ) a sociedade como Ordinata multitudo, organizada em um estado corporativo constituído de membros que se integram cada qual com sua hierarquia e utilidade específica em prol da unidade do corpo social. No caso luso-brasileiro, os dois corpos se sobrepunham em um só, em que a Igreja Católica e o Estado absolutista se fundiam em um só, conveniados e submetidos à figura pública do rei, uma espécie de metáfora divina, cabeça do corpo social e também da Igreja em Portugal. Cf. HANSEN, João Adolfo. Artes seiscentistas e teologia política. In: TIRAPELI, Percival (Org.). Arte sacra colonial: barroco memória viva. São Paulo: UNESP; Imprensa Oficial do Estado, 2001. p. 180189; e também JORDÃO, Paulo Vicente da Veiga. Corpo santo; alegorias do corpo místico no barroco mineiro. 1996. Trabalho de Conclusão de Curso (Especialização em Cultura e Arte Barroca) - Universidade Federal de Ouro Preto, Ouro Preto, MG, 1996. 
por exemplo, em 1711, assim como na sua elevação à condição de cidade, a partir de então denominada Mariana ${ }^{34}$, em 1745, foram a "capacidade" e a "comodidade" de sítios mais planos que constituíram a "conveniência”. Na ereção de Vila Rica, atual Ouro Preto, três meses depois da elevação da Vila do Carmo, as "conveniências" eram oportunamente as do "comércio", conveniências essas capazes de compensar, no juízo dos moradores convocados e na prudência do governador, Antonio Albuquerque Coelho de Carvalho, o excesso de acidentes de um sítio considerado por este como "não muito acomodado"35. Vale ressaltar que a análise dos termos de ereção das primeiras vilas ${ }^{36}$ de Minas Gerais foi decisivamente importante para a formulação da hipótese que considerava extremamente importante o papel do decoro na implantação e regulação dos processos de formação dessas povoações.

Fundada a "vila", instalava-se a câmara, que a partir de então concentrava outros processos povoadores que se pode sistematizar $\mathrm{em}^{37}$ :

1) Adequação das estruturas construidas preexistentes: concessão de aforamentos sobre propriedades já estabelecidas por moradores; "licenças" para "reforma”, reconstrução e "retificação" de casas mais "decentes" e "seguras", com materiais mais dignos, como o barro e a telha, em substituição à palha; "endireitamento" e realinhamento de arruamentos, a fim de assegurar a "decência" da povoação; eventualmente construções ou "partes" destas deveriam ser "demolidas" para se atingir principalmente continuidade nos alinhamentos das vias, em nome da "conveniência" pública e da "formosura" da povoação;

2) “Aumento" da povoação e das edificações. No âmbito edilício, o termo "aumento", também freqüente na documentação pri-

33 Arquivo Público Mineiro, Seção Colonial-06, f. 14, 14v. Criação da Vila de Nossa Senhora do Ribeirão do Carmo. Vila do Carmo, 08 abr. 1711.

34 Arquivo Público Mineiro, Seção Colonial-86, f. 33. Criação da Cidade de Mariana. Lisboa, 23 abr. 1745.

35 Arquivo Público Mineiro, Seção Colonial-06, f. 20-21. Termo de ereção de Vila Rica. Vila Rica, 08 jul. 1711.

36 Além de Vila do Carmo e Vila Rica, 1711, Sabará (Vila Real de Nossa Senhora da Conceição do Sabará, 1711), Vila de São João del Rei (1713), Sêrro (Vila do Príncipe, 1714), Caeté (Vila Nova da Rainha do Caeté do Mato Dentro, 1714), Pitangui (Vila Nova do Infante, 1715).

37 Os termos entre aspas se apresentam nos documentos de época. 
mária, significava, naquele tempo, tanto expansão física como "acrescentamento" 38 de "dignidade", assegurada através de: abertura de "praças" e novos "arruamentos" melhor "alinhados" e "decentes"; concessão de novos aforamentos para edificação de novas casas; construção de novos edifícios públicos, câmara e cadeia, chafarizes e pontes; construção "ornada" de capelas leigas e igrejas paroquiais; consolidação de largos e praças;

3) "Conservação" das várias "partes" da povoação: "reformas", "reparos" e "correições" urbanas parcelares, ou seja, em "partes" da povoação, públicas e particulares, que visavam a manutenção "conveniente" da sua estrutura física e a "correção" de sua aparência; manutenção da "comodidade", da "decência" aparente, da "limpeza" e do "asseio" da povoação.

Além dos vereadores e juízes ordinários, arruadores e juízes de ofícios das câmaras, outros agentes - administradores coloniais e metropolitanos - participavam diretamente desses processos povoadores: ouvidores e corregedores; superintendentes, oficiais e eventualmente engenheiros militares; procuradores dos moradores e das irmandades; governadores da capitania; o bispo, no caso particular de Mariana, sede do Bispado instalado na capitania em 1748, e inclusive o rei Dom João V, "cabeça" da Igreja em Portugal, conselheiros e secretários, agentes decisivos no processo de reforma e acomodação de Mariana sobretudo na década de 1740. Orientando esses processos povoadores e seus agentes, identifiquei procedimentos e princípios bastante significativos ao decoro e conveniência dos edifícios e povoações, pertinentes a uma verdadeira estrutura artístico-construtiva setecentista de que efetivamente participavam os agentes acima especificados, conforme cabedais e hierarquias. 0 "decoro", ou a "conveniência", enquanto "preceito regular", constituía uma orientação prudencial, um "meio", desde a eleição dos sítios para instalação das vilas, mas também um "fim" a ser alcançado, efetivado pela consecução e também pela conservação tanto da "utilidade" quanto da "aparência" "decente" da povoação e de suas "partes". "Vistorias" e "correições" dos vereadores e juízes, porventura acompanhados por arruadores, mestres e juízes de ofício, procuravam garanti-las em relação aos edifícios públicos mas também em relação aos particulares, impondo "reformas" ou até mesmo "demolições"

38 Cf. BLUTEAU, Raphael. Augmentar; Augmento. In: Vocabulário portuguêz, e latino, áulico, anatomico, architectonico... Coimbra: Real Collegio Das Artes da Companhia de Jesus, 1712. v. 1. p. 670. 
de "partes" que estivessem comprometendo a "utilidade", o "asseio" e a "formosura" da "res publica" edificada. A compreensão desses processos orientados pelo decoro permitiu constatar uma noção de povoação a ser constituída e conservada desde suas "partes", adequadas e íntegras em dignidade e decência, integradas hierárquica e convenientemente, entre si e no todo do "corpo místico" do reino - um organismo urbano em permanente acomodação teológico-retórica. A arquitetura e a povoação, além de sua utilidade ordinária, serviam à política teológica do reino católico português. 0 decoro, enquanto preceito fundamental da ética e da retórica setecentistas, participava fundamentalmente dessa concórdia de conveniências a serem efetivadas no âmbito urbano. Em sua comodidade e aparência teológico-retóricas, essas "povoações", que gosto de denominar, por tudo isso, "convenientes", eram recebidas também como discursos, discursos sobretudo teológico-retóricos, cujas alegorias e "ornatos" ("metáforas da arquitetura", nos termos de Emanuelle Tesauro) e demais dignidades efetuavam uma representação bastante conveniente do reino e de sua política colonizadora de caráter teológico. A povoação não poderia ser apenas um discurso, mas não se pode ignorar que este caráter, de discurso, tenha sido um dos pressupostos que fundamentavam sua constituição e conservação. A "comodidade" da povoação, por exemplo, era uma utilidade imprescindível, uma virtude necessária, freqüentemente solicitada nos termos de vereação e atas da câmara, bandos, correições etc. Satisfeita como proveito, a "comodidade" dos vários "lugares", vilas e arraiais de seus termos corporificava uma dignidade inerente à instituição genérica denominada "povoação". 0 efeito proveitoso advindo do uso ordinário e satisfatório das comodidades urbanas e dos caminhos encenava um discurso mais do que verossímil, que era lido pela colonização como uma dignidade urbana. Esse efeito proveitoso representava - tornava presente, literalmente - uma capacidade, uma "aptidão" (do latim aptum - um dos sinônimos latinos para a noção de decorum) da República católica em proporcionar o "bem comum" e a satisfação de suas necessidades genéricas. Não se pode esquecer que nos seiscentos e setecentos luso-brasileiros a produção artística - e sobretudo a produção artísticoconstrutiva - era pensada em virtude de sua utilidade ${ }^{39}$. Não se produzia segundo a noção moderna de autonomia da arte. Elas obedeciam sempre a um propósito de utilidade. A beleza deveria

39 Cf. HANSEN, João Adolfo. Artes seiscentistas e teologia política. In:

TIRAPELI, Percival (Org.). Arte sacra colonial: barroco memória viva. São Paulo: UNESP; Imprensa Oficial do Estado, 2001. p. 180-189. 
ser, acima de tudo, uma conveniência; ou melhor, uma reunião arguta, perspicaz e versátil, de conveniências concordadas. Conveniências políticas, teológicas, de gênero, de estilo, de assunto, de recepção e utilização. Os artistas e artífices dos séculos XVII e XVIII luso-brasileiros não criavam para contribuir para a História da arte, tampouco para serem alvos de um juízo estético autônomo, a que as categorias modernas - anacrônicas para esse contexto retórico - acabam induzindo. A competência do artista ou do artífice seria literalmente "louvada", ou seja, reconhecida por mestres do respectivo ofício eleitos anualmente pelos pares ou eventualmente pelas irmandades, se ele conseguisse acomodar engenhosa e convenientemente as distintas circunstâncias envolvidas na concepção, produção e recepção da obra: os riscos e modelos (porventura emulando-os), os materiais, os lugares de implantação e disposição, os ornatos capazes de ultimar a elocução e os efeitos apropriados aos destinatários. As artes possuíam finalidades e destinações específicas, finalizandose, por assim dizer, no fundamento mesmo que as justificava. Deus era a causa primeira, e também o fim, de todas as coisas, sobretudo nas monarquias católicas ibéricas. Assim como os sermões, a pintura, a imaginária, as festas, a música etc., a arquitetura e a povoação setecentistas discursavam; encenavam, persuasória e permanentemente, o "theatrum sacrum" 40 dos valores e propósitos católicos que fundamentavam a ética cristã contra-reformista. É o que permite explicar o preceito do "decoro" aparecer tão freqüentemente requerido nas fontes documentais primárias como "decência”, uma das várias sinonímias para o termo ${ }^{41}$.

40 Sobre o entendimento contra-reformista, de raiz jesuítica, das práticas de representação artística luso-brasileiras serem propostas como "Theatrum Sacrum" - encenação sagrada dos fundamentos, pressupostos católicos e histórias sacras, cf. HANSEN, João Adolfo. Artes seiscentistas e teologia política. In: TIRAPELI, Percival (Org.). Arte sacra colonial: barroco memória viva. São Paulo: UNESP; Imprensa Oficial do Estado, 2001. p. 180-189.

41 Decência e decoro advêm de uma mesma raiz latina: "decet", "Convir a, ser conveniente, decente, decoroso, estar bem"; part. pres.: “decens", "conveniente, decente, que está bem”. Cf. SARAIVA, F. R. dos Santos. Novíssimo dicionário latino-português. Ed. Fac-sím. 1927. Belo Horizonte; Rio de Janeiro: Garnier, 2000. p. 338. Cf. também CAMARERO, Antonio. La teoría etico-estética del decoro en la antigüedad. Bahia Blanca: Universidad Nacional del Sur, 2000. Sobre a noção de "decência" como preceito contrareformista derivado da noção de "decorum", cf. BLUNT, Anthony. 0 Concílio de Trento e a arte religiosa. In: Teoria artística na Itália 1450-1600.

Trad. de João de Moura Jr. São Paulo: Cosacnaify, 2001. p. 142-181. 
Desenvolvi esses e outros aspectos em dissertação de mestrado, cotejando a documentação primária e os tratados coevos, bem como os remanescentes físicos dessas povoações, principalmente em Ouro Preto e Mariana; importando aqui, todavia, apenas resumir minhas conclusões. Para um maior aprofundamento, remeto o leitor a outros textos publicados recentemente ${ }^{42}$. As compreensões que o estudo do decoro proporcionou aos processos povoadores em Minas Gerais colaboram com a tese de que as povoações coloniais luso-brasileiras merecem ser analisadas também com a aceitação de uma noção mais abrangente de "regularidade", entendida sobretudo como "observância" de "preceitos" e "regras" (abundantes naqueles tempos) da "arte" de povoar, edificar e arruar. 0 maior ganho que se pode obter não é conseguir enxergá-las como povoações regulares, mas o que se pode trazer de pesquisas e análises que procurem reconstituir também, concomitantemente, essas "regras" e "preceitos" da $\operatorname{arte}^{43}$. Sob o crivo formalista de uma noção de regularidade exclusivamente geométrica, ou mesmo de uma classificação dedutiva, "barroco" ou "rococó", pouco se acrescenta ao conhecimento dessas povoações e de seus regimes retóricos de concepção, produção e recepção. Ademais, o decoro parece ter sido, e não o será apenas em Minas Gerais, um dos princípios basilares daquela "Escola portuguesa de urbanismo", denotada por Eduardo Horta Correia - como ele mesmo salientou: uma "escola" contemplada muito mais por "princípios" do que por modelos formais rígidos de configuração urbana ${ }^{44}$.

42 BASTOS, Rodrigo Almeida. A arte do urbanismo conveniente: o decoro na implantação de novas povoações em Minas Gerais na primeira metade do século XVIII. In: PEREIRA, Sônia Gomes (Org.) Anais do VI Colóquio luso-brasileiro de história da arte. Rio de Janeiro: CBHA/UFRJ/UERJ/PUC-Rio, 2004. v. 2, p. 667-677; também BASTOS, Rodrigo Almeida. Lacunas da historiografia da arquitetura desenvolvida no Brasil no século XVIII. Cadernos de arquitetura e urbanismo da PUC-Minas, Belo Horizonte, v. 11, n. 12, p. 51-59, dez. 2004; também BASTOS, Rodrigo Almeida. 0 decoro e o urbanismo conveniente lusobrasileiro na formação da cidade de Mariana, Minas Gerais, meados do século XVIII. Revista Barroco, Belo Horizonte, n. 19, p. 273-296, maio 2005; também BASTOS, Rodrigo Almeida. 0 regime retórico da estrutura artístico-construtiva das vilas setecentistas no Brasil-colônia. In: REUNIÃo ANUAL DA SOCIEDADE BRASILEIRA PARA O PROGRESSO DA CIÊNCIA, 56., 2004. Cuiabá. Anais... Cuiabá: SBPC, 2004. Disponível em: <http://200.189.244.60/programa_ sbpc56ra/sboccontrole/textos/RodrigoBastos.htm>.

43 Desenvolvendo suas pesquisas no âmbito das letras seis e setecentistas, o professor João Adolfo Hansen (FFLCH-USP) defende uma reconstituição histórica dos preceitos e regimes contemporâneos às produções artísticas do período. 0 caminho aberto para as "belas letras" promete ser bastante proveitoso também às demais artes. 
Nos últimos anos, vem se consolidando a idéia de que um dos aspectos mais característicos da colonização portuguesa teria sido uma certa "adaptabilidade" às "conjunturas" textos existentes, advinda de esmeradas práticas e de um certo "pragmatismo" objetivo da empresa colonizadora. Na conclusão de sua tese, Beatriz Bueno cogitou ser "talvez" a "adaptação" uma "palavra de ordem" no cotidiano dos engenheiros militares formados no universo luso-brasileiro ${ }^{46}$. Contribuindo para essa disposição portuguesa para a "adaptação", preciso dizer que em Minas Gerais a consideração da "regra" do decoro representou justamente, como temos visto, uma regularidade primordial de adequação, orientada à conveniência e à adaptação aos contextos e circunstâncias humanas e políticas envolvidas, aos sítios e suas construções preexistentes - os "arraiais" sobre os quais se fundaram as vilas. A partir daí, essas "novas povoações", fundamentais à permanência dos povos e efetiva "conquista" colonial, estavam condicionadas a aumentar e a se conservar sob requisições de conveniência, decência e dignidade urbanas concordantes não apenas com suas novas condições hierárquicas, mas também com a política teológica e fiscal da coroa portuguesa. A disposição pela "adaptação" parece ter resultado, pois, não apenas de um pragmatismo ou de uma tradição da política de colonização portuguesa. Foi certamente dependente desses, mas há que se considerar que foi também estimulada, por assim dizer internamente, pela orientação de um princípio ético-retórico - o decoro - que aconselhava exatamente essa disposição para a adaptação, visando múltiplos âmbitos de conveniência.

0 estudo específico da Vila de Nossa Senhora do Carmo nos anos antecedentes à sua elevação à condição de cidade reafirmou a pertinência de se falar de uma regularidade primordial de adequação. Dediquei um capítulo da dissertação exclusivamente ao estudo do decoro na conformação de Mariana, no qual foi possível constatar o caso mais eloqüente - sob a consideração

44 HORTA CORREIA apud ROSSA, Walter. A cidade portuguesa. In: PEREIRA, Paulo (Org.). História da arte portuguesa. Lisboa: Círculo de Leitores, 1995. v. 3. p. 268.

45 ROSSA, Walter. No primeiro dos elementos: dados para uma leitura sintética do urbanismo e da urbanística portugueses da idade moderna. Revista Oceanos: a construção do Brasil urbano, Lisboa, n. 41, p. 22, jan./mar. 2000.

46 Cf. BUENO, Beatriz Piccolotto Siqueira. Desenho e desígnio: o Brasil dos engenheiros militares (1500-1822). 2001. 2 v. Tese (Doutorado em Arquitetura) - Faculdade de Arquitetura e Urbanismo da Universidade de São Paulo, São Paulo, 2001. p. 711. 
desse preceito, Mariana não chega a ser uma "exceção", como defendem muitos estudiosos quando a temática é regularidade geométrica - de um processo pelo qual passavam também outras povoações. Apesar de plantas de Mariana apresentarem conformações ortogonais bastante rígidas (FIG. 2), a efetiva "situação" da cidade evidencia uma circunstanciada e flexível acomodação (FIG. 3 e 4). Os arruamentos efetivos são bastante retilíneos mas não chegam a obedecer à estrita ortogonalidade.

Por causa das inundações do Ribeirão do Carmo, principalmente a de 1737, os vereadores do "senado da Câmara" de Mariana declararam a necessidade de arruamentos "mais convenientes" ${ }^{\prime 7}$ do que os de antes das destruições. Solicitaram inclusive a participação do próprio rei nas resoluções de âmbito povoador (leia-se urbanístico), influindo em matérias que solucionassem seguramente os problemas da cidade. Arruamentos já haviam sido abertos no sítio "mais cômodo" dos pastos, para a regularização dos quais a Fazenda Real inclusive aforou chãos para os moradores mais afligidos. Intervenções parcelares paliativas foram concebidas, sobretudo para conter as inundações do ribeirão, até que, em 02 de maio de 1746, D. João V solicitou a execução de uma "planta" ${ }^{\prime 8}$ capaz de proporcionar, nos termos requerentes do engenheiro e governador da capitania, Gomes Freire de Andrade, uma "nova povoação" no referido sítio dos pastos. Tudo indica que os "arruamentos convenientes" foram "convenientemente" adaptados às aberturas preexistentes, empreendidos por ocasião das inundações. Na já mencionada ordem régia que solicitou a execução da planta, o rei ainda recomendou que, ao se "praticar o referido", dever-se-ia, atente-se, "observar a boa ordem que fica estabelecida na situação da Cidade“. Se necessário fosse, acrescentou ainda o rei e discípulo do padre jesuíta Luiz Gonzaga, dever-se-ia também demolir "parte de algum edifício" que comprometesse a comodidade e a "formosura das ruas", prevalecendo a conveniência pública do "bem comum" em detrimento das "conveniências particulares"49. Se o decoro, em sua recomendação primordial de adequação, reconhecido pelo jesuíta Luiz Gonzaga junto às noções de "aparência" e "formosura", zelava pela ajuizada consideração "por ordem" às preexis-

47 Arquivo Histórico Ultramarino Brasil/MG Cx. 42, doc. 87, p. 215. Representação dos oficiais da Câmara da Vila do Carmo. Vila do Carmo, 2? ago. 1743.

48 Arquivo Público Mineiro, Seção Colonial-45, f. 28. Ordem régia sobre a planta para se fazer a Cidade Mariana no sítio dos pastos”. Lisboa, 02 maio 1746.

49 Arquivo Público Mineiro, Seção Colonial-45, f. 28. Ordem régia sobre a planta para se fazer a Cidade Mariana no sítio dos pastos”. Lisboa, 02 maio 1746. 
tências éticas, naturais e construídas, seria necessário adaptálas às novas estruturas urbanas - "observar a boa ordem que fica estabelecida na situação da cidade". "Estabelecer" a cidade no sítio, ou seja, situá-la, "estabelecer-lhe" "situação" de "boa ordem", efetivada por dignidade, conveniência e formosura de edifícios e arruamentos. Um "boa ordem", no caso de Mariana, de evidência própria, poder-se-ia dizer apropriada, pois ajustada e conveniada ao sítio que lhe dá "assento"; "disposta" por orientação de uma "regularidade" primordial de "regras" e "preceitos" "observados", decoro e ordem, "boa ordem", literalmente, de conveniência e adequação. A definição apresentada pelo também jesuíta Raphael Bluteau para o vocábulo "Ordem" evidencia antes um princípio de "conveniência", considerado na "disposição" ou "colocação" das cousas: "ORDEM. Disposição, assento, colocação das cousas no lugar, que lhe convem". Afiança Bluteau que, algumas vezes, se poderá dizer "dispositio", recorrendo ao uso que lhe dá o rétor Cícero ${ }^{50}$. É por isso que a "ordem” urbana não poderia ser exclusivamente uma qualidade determinada a priori, como induz a noção de regularidade estritamente geométrica; porque tudo indica que essa "ordem" deveria ser necessariamente "estabelecida" na ação circunstanciada de "situar", de "dispor", de "assentar" "convenientemente" a cidade.

Em 1936, com Raízes do Brasil, Sérgio Buarque de Holanda reafirmou uma tradição historiográfica segundo a qual: $1^{\circ}$ ) os povoadores portugueses não cogitaram da "ordem" e $2^{\circ}$ ) por "regular" se deveria compreender a cidade de atributos prévios e uniformemente geométricos - no que se vê a influência do paradigma hispano-americano do damero. Para expor sua compreensão do processo povoador português, Holanda assimilou trechos do Sermão da sexagésima, apresentado pelo padre Antônio Vieira na Capella Real em 1655. Embora tenha servido de mote para o desenvolvimento das hipóteses de Holanda, o sermão de Antonio Vieira contém aspectos e valores - justamente os utilizados por Holanda - que permitem reafirmar o que está proposto aqui neste texto; na contramão, pode-se dizer assim, do que defendeu o eminente historiador brasileiro.

A matéria do Sermão da sexagésima é a própria instituição retórico-teológica do "Sermão". Antonio Vieira procurou examinar as razões que explicassem a falta de eficácia dos sermões de seu tempo na reforma dos fiéis, e para encontrá-

50 BLUTEAU, Raphael. Ordem. In: Vocabulário portuguêz, e latino, áulico, anatomico, architectonico... Coimbra: Real Collegio Das Artes da Companhia de Jesus, 1712. v. 6, p. 102. 
las realizou um exame minucioso das partes e circunstâncias que condicionam a composição e a ação oratória do pregador, "semeador" da palavra de Deus ${ }^{51}$. Ao desenvolver o "estilo" a ser seguido pelo pregador, uma das cinco "circunstâncias" nele consideradas (pessoa, ciência, matéria, estilo e voz), Vieira tratou da "ordem" implícita à ação de "semear" com sermões, uma arte que teria mais de natureza do que propriamente de arte, em que a semente pode nascer "caia onde cair". "0 mais antigo pregador que houve no mundo", engenhou Vieira, "foi o Céu":

As palavras são as estrelas, os sermões são a composição, a ordem, a harmonia e o curso delas. Vede como diz o estilo de pregar do Céu, com o estilo que Cristo ensinou na terra? Um e outro é semear; a terra semeada de trigo, o Céu semeado de estrelas. 0 pregar há de ser como quem semeia, e não como quem ladrilha, ou azuleja. Ordenado, mas como as estrelas: Stellae manentes in ordine suo. Todas as estrelas estão por sua ordem; mas é ordem que faz influência, não é ordem que faça lavor. Não fez Deus o Céu em xadrez de estrelas, como os Pregadores fazem o sermão em xadrez de palavras. ${ }^{52}$

A "ordem" das estrelas seria uma espécie de modelo à ordem do "semeador" - pregador de palavras. Todas as estrelas estão "por sua ordem", mas não em ladrilhos de xadrez. Os sermões em "xadrez de palavras" não seriam adequados para semear, e o céu ensinaria ao pregador o "estilo da disposição" e das palavras, "claras", "distintas" e "altíssimas", cada parte "por sua ordem" $" 53$.

Aos que conhecem o texto de Sérgio Buarque de Holanda, em que as cidades hispano-americanas são exaltadas por sua regularidade e ordem (geométricas), ficam claras as correspondências estabelecidas com o texto de Antonio Vieira. Holanda foi muito arguto ao identificar o povoador português ao "semeador", todavia, ele inverteu o juízo de Vieira, o que é preciso restaurar. Conquanto não tenha sido considerado apropriado, por Vieira, o sermão em xadrez de palavras, a cidade exaltada por Holanda foi justamente a cidade em xadrez de ruas, construída

51 VIEIRA, Antonio. Sermão da sexagésima. In: Sermões. Organizado por Alcir Pécora. São Paulo: Hedra, 2003. p. 27-52.

52 VIEIRA, Antonio. Sermões. Organizado por Alcir Pécora. São Paulo: Hedra, 2003. p. 39-40.

53 VIEIRA, Antonio. Sermões. Organizado por Alcir Pécora. São Paulo: Hedra, 2003. p. 39-40. 
por "ladrilhadores" (espanhóis). Analogamente apropriada, consoante o engenhoso desenvolvimento de Vieira, não seria a cidade em "xadrez de ruas", mas sim a cidade de partes convenientemente dispostas e adequadas cada uma "por sua ordem" e natureza; como se depreende também quando a definição coeva de "ordem” é colhida em Bluteau, como vimos: "disposição" ou "colocação" de cada "cousa" no "lugar que lhe convém".

Se a arquitetura e a cidade, dentro do regime retórico característico das práticas de representação artística luso-brasileiras dos séculos XVII e XVIII, eram pensadas também como discurso, segundo a estratégia teológica de encenação persuasória e permanente (theatrum sacrum) dos pressupostos católicos contra-reformistas, esse discurso arquitetônico-urbano não poderia convir a outro gênero senão justamente o sermonário. Específica e metaforicamente, a povoação mineira do século XVIII constituía um persuasório e permanente sermão de pedras, necessário, útil e alegórico, representação verossímil do "corpo místico" e da política fundamentalmente teológica do reino português. Se o sermão era um discurso disposto e ornado de lugares-comuns (topoi) teológicos e retórico-poéticos, ordenado por preceitos regulares de decoro, conveniência e adequação, a cidade também o era, um discurso habitável construído, disposto e ornado de lugares-comuns arquitetônicos e urbanos, tópicas convalidadas pela longa tradição luso-brasileira de fazer cidades: ruas "direitas", ruas "novas" e "formosas", travessas, casarios caiados, casas de câmara e cadeia e pelourinhos, becos, largos, adros, passos e capelas, sobretudo capelas, "decentemente" "acomodadas" em "elevação" 54 , sobre ombreiras e cumes de morros. Elementos e aspectos que permitem identificar uma arte retórico-construtiva de prudentes juízos, consolidada por longas durações de tradições e costumes, práticas e preceitos regulares observados, destinada a ordenar, aumentar e conservar povoações convenientes.

54 Como recomendavam as Constituições primeiras do arcebispado da Bahia, ordenadas em 1707 pelo Bispo Sebastião Monteiro da Vide, concordantes com as postulações declaradamente "decorosas" do tratado regulador da arte e da arquitetura eclesiástica pós-tridentina (Instructiones fabricae et supellectilis ecclesiasticae), apresentado por São Carlos Borromeu em 1577. 


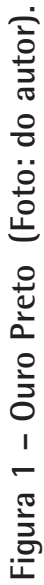

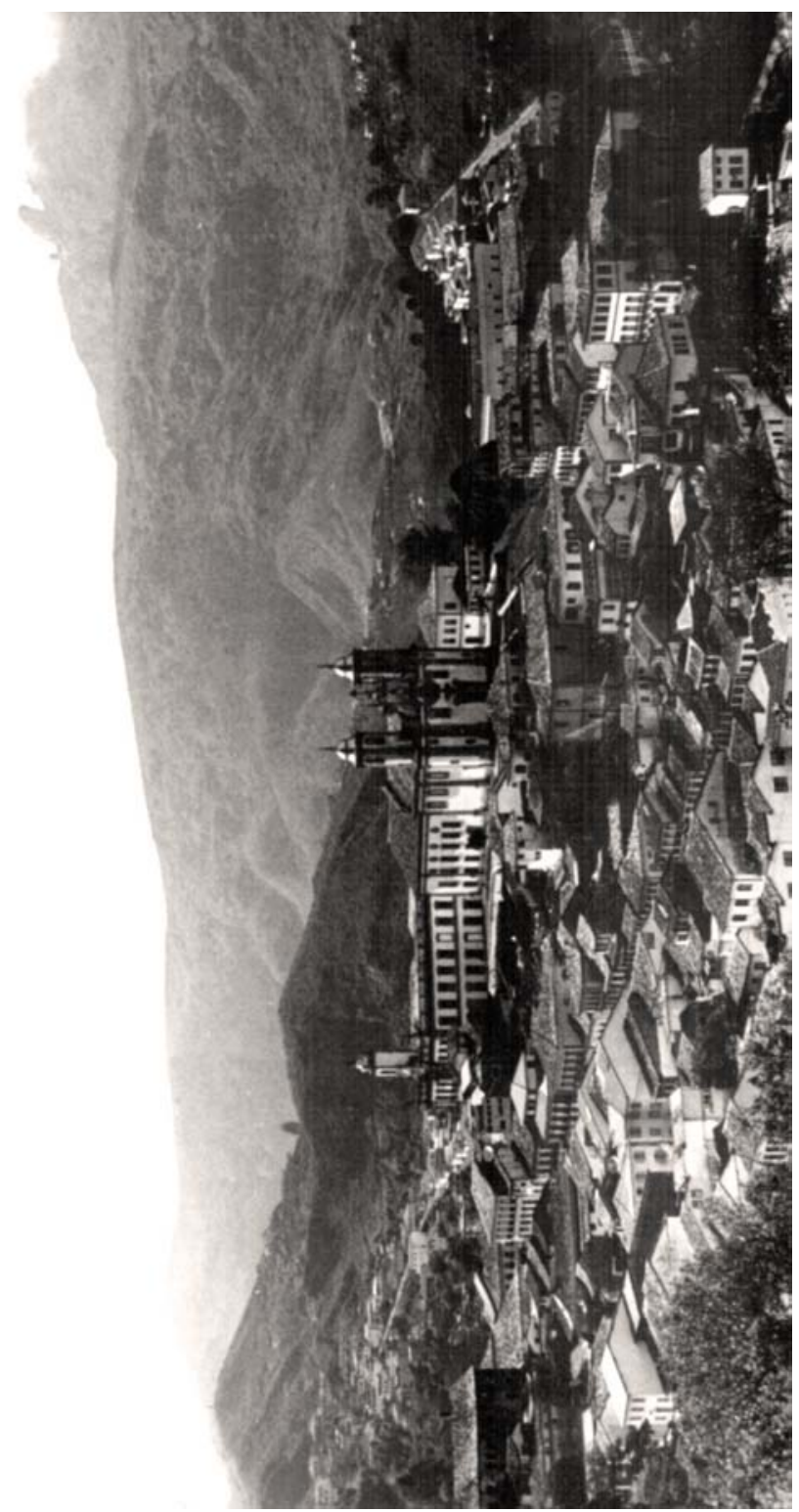

revista do ieb n 44 fev 2007 
Figura 2: "Plãta da cidade de Mariana" (meados séc. XVIII) (Fonte: Arquivo Histórico do Exército/RJ; foto do autor).

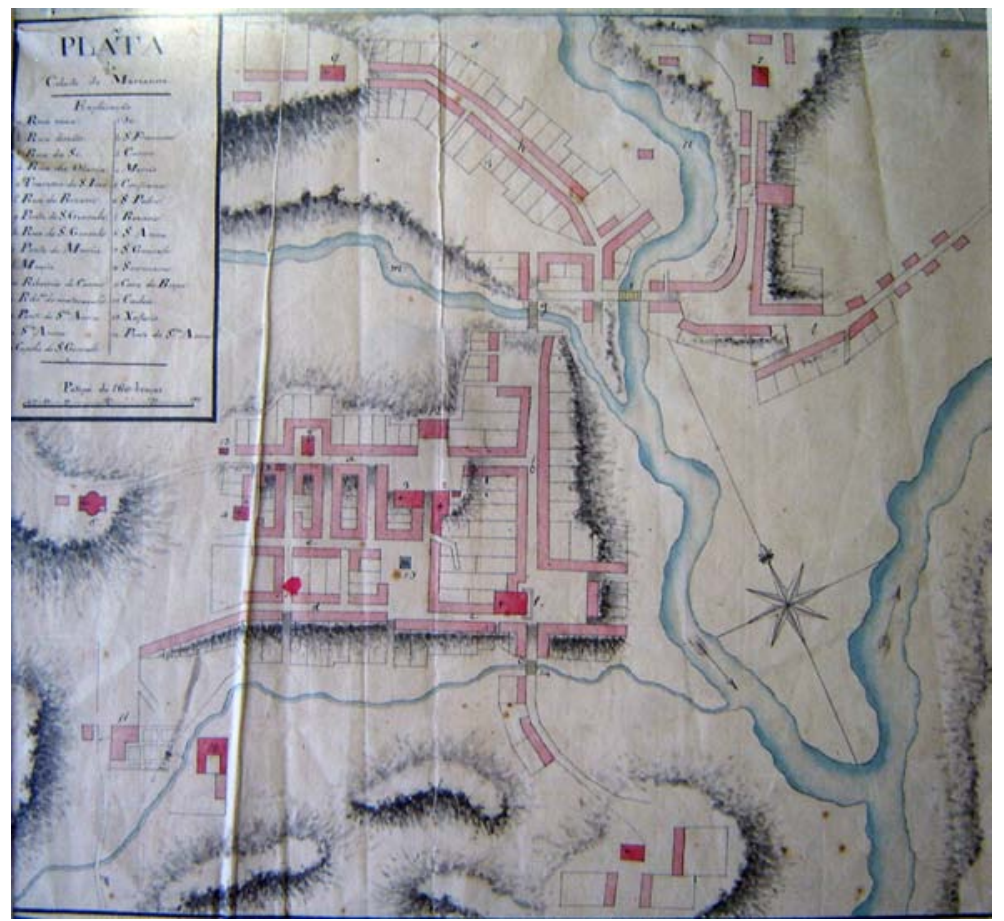


Figura 3: Planta atual do centro histórico de Mariana (Fonte: Inventário Monumenta de Ouro Preto e Mariana. UFMG/IPHAN).

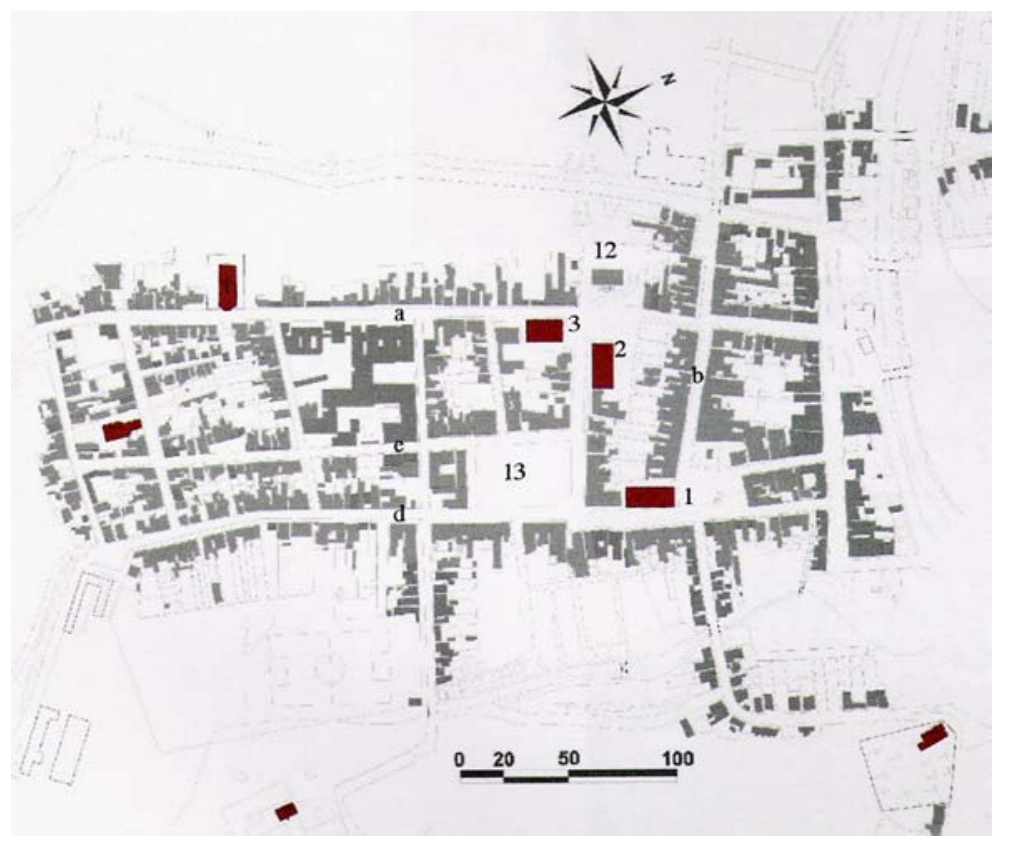




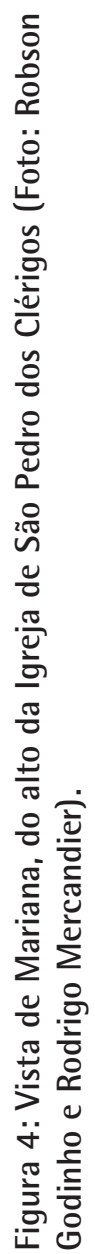

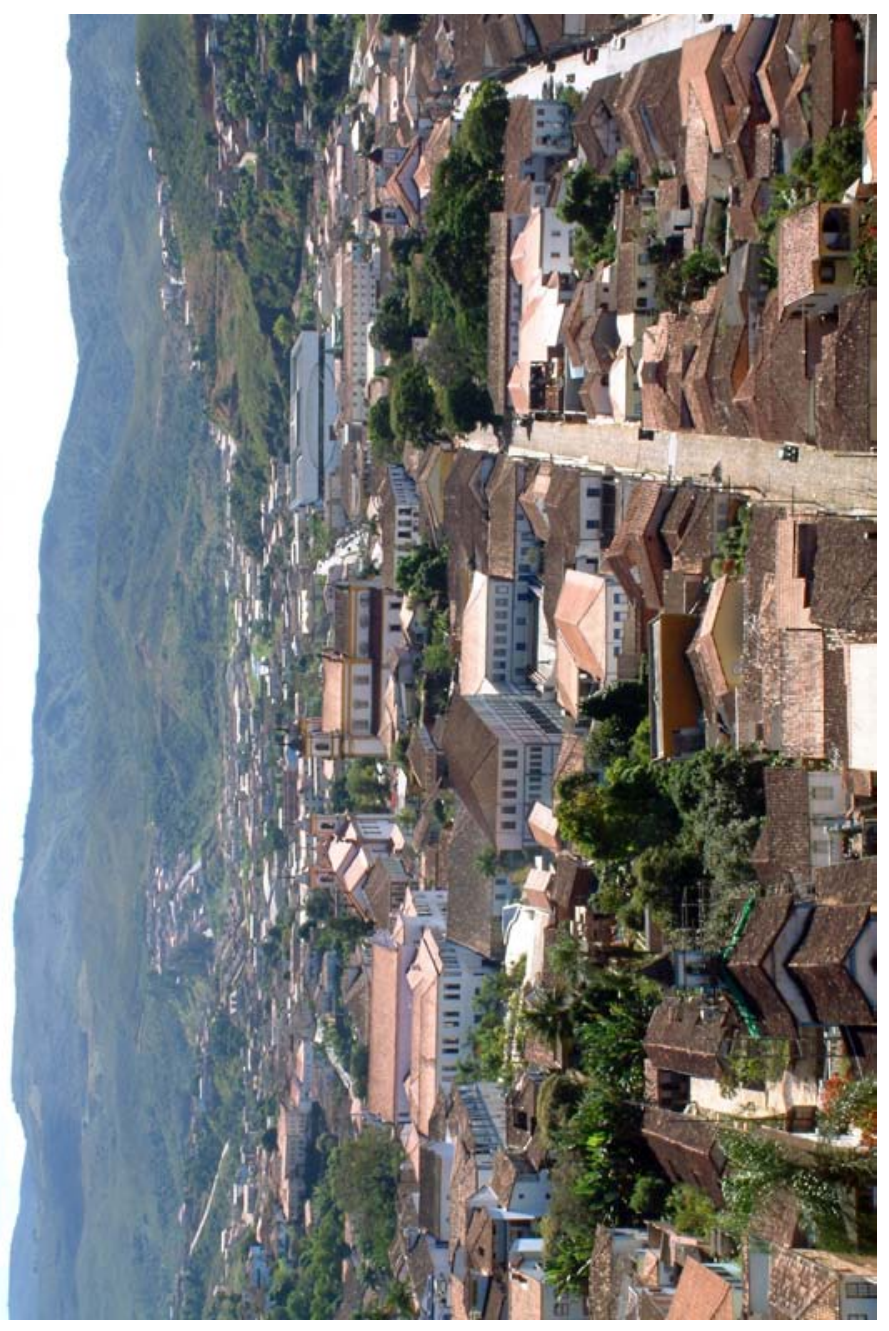

